\title{
PEMBERDAYAAN POTENSI KELOMPOK PETANI DENGAN PEMBUATAN KOPI JAHE SEBAGAI UPAYA PENINGKATAN NILAI JUAL PRODUK KOPI
}

\section{EMPOWERING POTENTIAL FARMER GROUP BY GINGER COFFEE PROCESSING IN EFFORT TO INCREASE THE VALUE OF COFFEE PRODUCT}

\author{
Oleh: \\ Dewi Handayani, Amrul Bahar, Dewi Jumiarni \\ Program Studi Pendidikan Kimia FKIP Universitas Bengkulu \\ Email: zidan1712@yahoo.com
}

\begin{abstract}
Tapa Gedung village is a village with the majority of the population are farmers. Coffee beans in this village are usually directly sold to buyers without any further processing into coffee powder. The people's income are still very low. Therefore, the team did a variation dedication and creativity in the coffee beans produced by the community making ginger coffee. Method offered in this proposal is debriefing, direct practice, mentoring, monitoring, evaluation, packaging and marketing. Results of these service activities show that the community is very anthusiastic due to variations in the development of the coffee powder into a coffee flavor of ginger. The selling price of coffee is also increased. Another advantage of coffee products is able to enhance the creativity and people's revenue. With this program, people become creative to make a variety of products. With the products that are useful and economically valuable, of course will generate revenue for the community, so expect the public revenue that average below the minimum wage could increase at least not under UMR. This program also gave knowledge and expertise (skills) community in the Village of Tapak Gedung in ginger processing and trained about packaging and marketing of coffee ginger product.
\end{abstract}

Keywords: Ginger coffee, Desa Tapak Gedung, Coffee Farmers

\section{PENDAHULUAN}

Luas areal pertanaman kopi robusta di Kabupaten Kepahiang seluas 24.064 hektar (tahun 2010). Sejak tahun 2007 sudah mulai dilakukan penyambungan sebanyak 743 Hektar. Untuk penyambungan. Tahun 2010 sebanyak 60 Hektar dan rencana penyambungan 2011 seluas 75 hektar. Mulai tahun 2007 sampai dengan tahun 2013 telah melakukan penyambungan seluas 803 hektar lebih. Luas wilayah desa Tapak Gedung adalah $\pm 500 \mathrm{Ha}$ (Data dari Kepala Desa Tapak Gedung).

Secara administratif, Desa Tapak Gedung merupakan bagian dari Kecamatan Tebat Karai Kabupaten Kepahiang. Pada akhir tahun 2013, memiliki jumlah penduduk 1050 jiwa yang terdiri dari 496 jiwa pria dan 554 jiwa wanita, dengan tingkat kepadatan penduduknya sendiri mencapai kurang lebih 200 per $\mathrm{Km}^{2}$. Masyarakat suku Serawai yang 
mendiami Desa Tapak Gedung berasal dari Bengkulu Selatan dan Seluma. Desa Tapak Gedung Kepahiang dipimpin oleh Kepala Desa Sutarwijaya (sudah 2 periode) dan sekretaris desa Sudirman. Desa ini dihuni oleh masyarakat Suku Serawai dengan mayoritas mata pencarian penduduknya bertani kopi (90\%) selain bertani kopi penduduk juga menanam jahe terutama untuk lahan yang baru digarap sebelum panen kopi. Tanaman pertanian yang banyak ditanam warga adalah kopi jenis Arabika dan Robusha. Masa panen tanaman kopi adalah setahun sekali dan yang dijual oleh petani adalah bijinya saja. Hal inilah yang menyebabkan kondisi ekonomi masyarakat hanya tergantung dari penghasilan tahunan. Hasil penjualan biji kopi juga tergolong rendah sesuai dengan permintaan toke (orang yang membeli kopi).

Dari data survey langsung oleh tim Pengabdian Pada Masyarakat (PPM) ditemukan bahwa warga Desa Tapak Gedung tidak mengolah kopi menjadi bahan siap saji yang bernilai ekonomis, hanya menjual hasil buah kopi langsung ke toke baik buah basah maupun kering. Ini tentunya tidak ada upaya untuk meningkatkan nilai harga hasil panen kopi. Masyarakat hanya tergantung dari penghasilan tani yaitu buah kopi yang panennya 1 tahun sekali. Ketergantungan masyarakat terhadap hasil kopi ini menyebabkan masyarakat tidak mempunyai kreativitas dan kegiatan positif lainnya. Sedangkan potensi lain dari tanaman kopi masih dapat dikembangkan khususnya daun kopi. Menurut Kepala Desa Tapak Gedung, penghasilan masyarakat petani kopi rata-rata 5-10 juta rupiah per tahun $( \pm$ Rp 400.000 s.d Rp 800.000 / bulan). Pendapatan ini tergolong rendah bahkan masih di bawah upah minimum di Provinsi Bengkulu Rp 1.200.000 (Permenakertrans, 2012).

Selain itu, dampak dari tidak adanya kegiatan dan kreatifitas masyarakat, banyak pemuda-pemudi di Desa Tapak Gedung yang pengangguran. Dampak pengangguran dan kemiskinan cukup besar di desa Tapak gedung, diantaranya: kawin usia muda, pencurian, berkelahi, berjudi, sabung ayam, dan lain sebagainya. Tingkat pendidikan masyarakat tergolong rendah, masih banyak masyarakat yang tidak tamat SMP dan masih ada yang belum tamat SD.

Untuk itulah tim pengabdian penerapan Iptek tahun 2014 mengusulkan kegiatan pengolahan bubuk kopi jahe. Produk kopi jahe instan ini merupakan kombinasi kopi dengan jahe yang mana dibuat instan sehingga tidak ada residu/ampas yang ditinggalkan ketika diseduh. Kopi jahe ini sangat cocok diminum pada saat suasana udara yang dingin selain menyegarkan badan kopi ini juga dapat menghangatkan badan. Sifat khas jahe disebabkan adanya minyak atsiri dan oleoresin jahe. Aroma harum jahe disebabkan oleh minyak atsiri, sedangkan oleoresinnya menyebabkan rasa pedas. Minyak atsiri dapat diperoleh atau diisolasi dengan destilasi uap dari rhizoma jahe kering. Ekstrak minyak jahe berbentuk cairan kental berwarna kehijauan sampai kuning, berbau harum tetapi tidak memiliki komponen pembentuk rasa pedas. Kandungan minyak atsiri dalam jahe kering sekitar 1 - 3 persen. Komponen utama minyak atsiri jahe yang menyebabkan bau harum adalah zingiberen dan zingiberol. Oleoresin jahe banyak mengandung komponen pembentuk rasa pedas yang tidak menguap. Komponen dalam oleoresin jahe terdiri atas 
gingerol dan zingiberen, shagaol, minyak atsiri dan resin. Pemberi rasa pedas dalam jahe yang utama adalah zingerol. Penambahan jahe ini sangat bermanfaat dan sangat diminati oleh konsumen. Selain dapat menghangatkan badan, jahe juga bermanfaat untuk menbangkitkan nafsu makan (Koswara, 2007). Lebih lanjut Koswara (2007) menjelaskan bahwa jahe dapat merangsang kelenjar pencernaan, baik untuk membangkitkan nafsu makan dan pencernaan. Hal ini dimungkinkan karena terangsangnya selaput lendir perut besar dan usus oleh minyak asiri yang dikeluarkan rimpang jahe. Minyak jahe berisi gingerol yang berbau harum khas jahe, berkhasiat mencegah dan mengobati mual dan muntah.

Dalam rangka meningkatkan kreativitas dan pemanfaatan potensi Sumber Daya Alam (SDA) khususnya di daerah pedesaan, maka perlu dilakukan upaya yang otomatis untuk menerapkan berbagai alternatif peningkatan ekonomi yang terpadu dengan pengembangan wisata. Sehubungan dengan hal tersebut, maka salah satu upaya terobosan yang dilakukan adalah melaksanakan program pendampingan tentang pembuatan kopi jahe skala rumah tangga dan usaha kecil.

\section{METODE KEGIATAN}

Metode yang ditawarkan dalam usulan ini adalah pembekalan, praktek langsung, dan pendampingan untuk mengatasi permasalahan yang terjadi pada masyarakat desa Tapak Gedung, yaitu dengan menggunakan tiga tahapan pendekatan. Pembekalan secara khusus ditujukan kepada 2 kelompok petani kopi (Kelompok tani Serasan dan Seijoan) yang terdiri dari 10 orang per kelompok tani. Setelah program dilaksanakan, 2 kelompok tani tersebut terus melakukan pengimbasan kepada seluruh masyarakat di Desa Tapak Gedung. Dari ketiga metode yang digunakan untuk metode pertama terkait dengan perlunya peningkatan ekonomi dan mengatasi pengangguran, untuk pembekalan ini ditujukan secara luas kepada seluruh masyarakat Desa Tapak Gedung yang berminat mengikuti.

Beberapa tahapan metode yang digunakan adalah sebagai berikut:

\section{Pertemuan Awal}

Pertemuan awal adalah langkah menjalin kerja sama, observasi, dan persiapan kegiatan. Pertemuan awal dilakukan antara tim pengabdian dengan kepala desa beserta pengurus inti 2 kelompok tani Serasan dan Seijoan.

\section{Pembekalan}

Kegiatan ini dilaksanakan 2 hari dengan melibatkan 20 kepala keluarga dan anggota masyarakat lainnya. Pelaksanaan Pembekalan ini dilakukan dibalai pertemuan Desa Tapak Gedung. Tim pengusul kegiatan memberikan penjelasan tentang potensi yang dapat dihasilkan dari kopi jahe. 


\section{Praktek Pembuatan Kopi Jahe}

Secara singkat pembuatan bubuk kopi adalah sebagai berikut: Praktek pembuatan bubuk kopi diawali dari biji kopi yang kering, lalu biji kopi yang kering dipanaskan dikuali sampai biji kopi menjadi hitam seperti arang, selanjutnya biji kopi yang sudah hitam tersebut ditumbuk menggunakan mesin/tumbuk tradisional (lesung), sesudah ditumbuk lalu disaring dengan menggunakan penyaring sehingga didapat bubuk kopi halus yang siap digunakan.

Secara singkat pembuatan bubuk jahe adalah sebagai berikut: jahe diparut, lalu direbus sampe airnya menyerap habis, kemudian disaring, terakhir jemur hasil saringan sampai kering, dan terbentuk bubuk jahe. Selanjutnya dua bubuk ini digabung menjadi satu dengan perbandingan jahe : kopi adalah $1: 4$.

\section{Pendampingan, Monitoring dan Evaluasi}

Dari semua tahapan pembekalan dan terutama praktek pembuatan kopi jahe dilakukan pendampingan yang intensif sampai 2 kelompok tani kopi di Desa Tapak Gedung benar-benar memahami proses pembuatannya. Selama masa pendampingan ini terus terjadi interaksi dan diskusi terhadap semua permasalahan produksi sampai pemasarannya.

Monitoring dilaksanakan untuk melihat dan memastikan keberhasilan kegiatan setiap tahapan di atas dilaksanakan sesuai prosedur, terutama setelah tahap praktek oleh peserta kegiatan, dimulai pembuatan sampai pada produk yang siap disajikan. Hal yang paling penting juga dari semua tahapan adalah kebersihan dan rasa karena menyangkut dengan produk yang akan dikonsumsi langsung.

Evaluasi yang akan dilakukan untuk menilai keberhasilan kegiatan ini sudah disiapkan dalam bentuk instrumen, beberapa komponen penting yang dievaluasi adalah:

1. Melihat respon yang diberikan oleh peserta kegiatan (2 kelompok tani ; Serasan dan

Seijoan) terhadap arti pentingnya potensi SDA yang ada, potensi peningkatan ekonomi, dan mengentaskan pengangguran (selama proses pembekalan).

2. Mengevaluasi cara kerja kelompok tani dalam hal pembuatan kopi jahe terkait kesusuaian langkah dengan pengerjaannya, kebersihan, keindahan, dan rasa.

Jika tahapan ini belum memenuhi standar maka perlu diulang langkah-langkah pembuatannya.

\section{Pengemasan dan Pemasaran}

Kopi jahe harus dilindungi dengan cara menerapkan pengemasan sesuai sebelum pasarkan. Kemasan yang digunakan harus mampu melindungi produk dari absorbsi kelembaban atmosfir yang tidak hanya menyebabkan produk menggumpal (mengeras/memadat) juga mempercepat penurunan (deterioration) aroma. Kemasan standar yang digunakan saat ini kertas membran atau alumunium foil dan kaleng dari bahan timah. Kaleng kosong biasanya disediakan bersama dengan tutup, cincin dan 
membran yang dimasukkan menuju mesin pengisi dalam keadaan posisi terbalik. Setelah pengisian, alas kemasan dikelim dan kertas lebel ditempelkan dikemasan. Atau juga dengan sederhana dikemas dengan plastik yang sudah dilabeli merk.

Pemasaran dapat dengan mencari langganan langsung, promosi ke media, dan dapat memajang produk di daerah wisata air terjun Curug Embun yang ada di Desa Tapak Gedung. Tempat wisata ini sangat ramai dikunjungi wisatawan sehingga sangat efektif untuk promosi sekalian untuk produk oleh-oleh khas Tapak Gedung.

\section{HASIL DAN PEMBAHASAN}

Kegitan Pengabdian dilakukan di Desa Tapak Gedung Kabupaten Kepahiang. Persiapan awal yang dilakukan adalah persiapan alat dan bahan, ruangan, perlengkapan di lapangan dan lain-lain. Persiapan alat dan bahan dilakukan pada bulan Mei-Juni 2014. Sudah dibuat panduan pembuatan kopi jahe. Koordinasi dengan kepala desa dan kelompok tani sudah dilakukan. 2 Kelompok Tani Serasan dan Seijoan juga sudah menyiapkan biji kopi dan jahe sebagai bahan pembuatan bubuk kopi jahe. Lokasi pembuatan kopi jahe sudah disiapkan di rumah kepala Desa Tapak Gedung. Praktek pembuatan kopi jahe pada tanggal 14 Juli 2014.

Metode yang digunakan dengan tiga metode pendekatan yaitu pembekalan, praktek terbimbing, dan evaluasi. Tahap kegiatan pembekalan sudah dilakukan. Kegiatan ini melibatkan 20 kepala keluarga. Pelaksanaan Pembekalan ini dilakukan di rumah kepala Desa Tapak Gedung. Tim pengusul kegiatan memberikan penjelasan tentang potensi yang dapat dihasilkan dari kopi jahe. Manfaat yang dapat diperolah dari pengolahan produk kopi jahe diantaranya yaitu: (1) Dapat meningkatkan kreativitas dan pendapatan masyarakat. Dengan adanya kegiatan ini, masyarakat menjadi kreatif membuat berbagai produk yang bermanfaat. Dengan adanya produk yang bermanfaat dan bernilai ekonomis tentunya akan menghasilkan pendapatan bagi masyarakat, sehingga diharapkan pendapatan masyarakat yang rata-rata dibawah UMR bisa meningkat minimal tidak di bawah UMR; (2) Dapat mencegah/menyembuhkan berbagai penyakit. Disebutkan bahwa kopi mengandung alkaloid, saponin, flavonoid, dan polifenol (Agromedia Pustaka, 2008). Menurunkan darah tinggi bagi penderita darah tinggi/hipertensi, menambah stamina dan vitalitas, menghangatkan badan dan melancarkan saluran pernafasan, mengurangi risiko penyakit jantung dan diabetes, menyegarkan badan, dan mengurangi asam urat (Resa Lelyana, 2008); (3) Memberikan pengetahuan (knowledge) dan keahlian (skill) masyarakat di Desa Tapak Gedung tentang pembuatan kopi jahe; (4) Memberikan pengetahuan kepada masyarakat tentang pengemasan dan pemasaran hasil produk kopi jahe; dan (5) Mengurangi pengangguran dan dampak yang ditimbulkan pengangguran tersebut.

Pada saat praktek pembuatan kopi jahe, masyarakat sangat antusias hal ini dikarenakan adanya variasi pengembangan rasa bubuk kopi menjadi kopi jahe. Harga jual kopi juga semakin meningkat. Tahap berikutnya adalah pendampingan, monitoring dan evaluasi. 
Dari semua tahapan pembekalan dan terutama praktek pembuatan kopi jahe dilakukan pendampingan yang intensif sampai 2 kelompok tani kopi di Desa Tapak Gedung benar-benar memahami proses pembuatannya. Selama masa pendampingan ini terus terjadi interaksi dan diskusi terhadap semua permasalahan produksi sampai pemasarannya.

Monitoring dilaksanakan untuk melihat dan memastikan keberhasilan kegiatan setiap tahapan di atas dilaksanakan sesuai prosedur, terutama setelah tahap praktek oleh peserta kegiatan, dimulai pembuatan sampai pada produk yang siap disajikan. Hal yang paling penting juga dari semua tahapan adalah kebersihan dan rasa karena menyangkut dengan produk yang akan dikonsumsi langsung. Kegiatan monitoring dilakukan langsung oleh tim pelaksana pengabdian. Dari monitoring yang dilakukan oleh tim pelaksana, kelompok tani sudah membuat bubuk kopi jahe sesuai dengan prosedur/ panduan yang sudah disiapkan tim.

Evaluasi yang akan dilakukan untuk menilai keberhasilan kegiatan ini sudah disiapkan dalam bentuk instrumen, beberapa komponen penting yang dievaluasi adalah melihat respon yang diberikan oleh peserta kegiatan (2 kelompok tani ; Serasan dan Seijoan) terhadap arti pentingnya potensi SDA yang ada, potensi peningkatan ekonomi, dan mengentaskan pengangguran (selama proses pembekalan). Mengevaluasi cara kerja kelompok tani dalam hal pembuatan kopi jahe terkait kesusuaian langkah dengan pengerjaannya, kebersihan, keindahan, dan rasa.

Tahap berikutnya adalah tahap pengemasan dan pemasaran. Pada tahap ini pengemasan baru dilakukan pada kantong plastik kecil yang diberi label "Kopi Jahe Curug Embun Tapak Gedung". Pemasaran dilakukan dengan mencari langganan langsung, promosi ke media menggunakan internet via facebook dan promosi di Berniaga.com. Teknik pemasaran yang lain rencananya yaitu dengan memajang produk di daerah wisata air terjun Curug Embun yang ada di Desa Tapak Gedung. Tempat wisata ini sangat ramai dikunjungi wisatawan sehingga sangat efektif untuk promosi sekalian untuk produk oleholeh khas Tapak Gedung.

\section{KESIMPULAN DAN SARAN}

\section{Kesimpulan}

Dari kegiatan pengabdian ini maka dapat disimpulkan, diantaranya adalah masyarakat memperoleh pengetahuan (knowledge) dan keahlian (skill) tentang pengolahan biji kopi dan jahe menjadi kopi jahe. Masyarakat mengetahui bahwa kopi jahe dapat dijadikan alternatif untuk meningkatkan perekonomian masyarakat. Masyarakat sudah mengetahui potensi bubuk kopi dapat dikembangkan dengan mencampur bubuk jahe menjadi "Kopi Jahe Curug Embun Tapak Gedung” yang mempunyai cita rasa yang khas, enak dan sehat. Pihak pemerintah daerah memfasilitasi secara berkelanjutan pengembangan pembuatan kopi jahe sehingga dapat dikembangkan untuk skala industri. 


\section{Saran}

Melihat respon dan hasil yang baik yang ditunjukkan oleh masyarakat Desa Tapak Gedung Kabupaten Kepahiang, maka sebaiknya program ini dilaksanakan juga untuk daerah lain di Provinsi Bengkulu.

\section{DAFTAR PUSTAKA}

Agromedia Pustaka, 2008, Buku Pintar Tanaman Obat, Redaksi Agromedia Pustaka, Jakarta.

Koswara, S., 2007, Jahe, Rimpang dengan Sejuta Khasiat, www.ebookpangan.com (diakses pada tanggal 29 April 2014).

Permenakertrans No. 13 Tahun 2012, Komponen dan Pelaksanaan Tahapan Pencapaian Kebutuhan Hidup Layak, http://fspmiptbi.org/daftar-umr-ump-umk-tahun-2013 (diakses jam 10.57 tanggal 29 April 2014). 